\title{
PERBEDAAN TEKANAN DARAH SISTOLE DAN DIASTOLE SEBELUM DAN SETELAH KERJA PADA PEKERJA YANG TERPAPAR BISING DI PT X
}

\author{
Yazid Albustomi ${ }^{1}$, Denny Ardyanto W. ${ }^{2}$ \\ ${ }^{\mathbf{1}}$ Program Studi Kesehatan Masyarakat, Fakultas Kesehatan Masyarakat, Universitas Airlangga \\ ${ }^{2}$ Departemen Keselamatan dan Kesehatan Kerja. Email: yazid-a-11@fkm.unair.ac.id
}

\begin{abstract}
The high intensity of the noise that occurs in the work area will cause health problems such as changes in blood pressure and hearing disorders. This study is observational cohort study design. The study population was taken in accordance with the terms of inclusion that has been determined, in order to obtain the population is 36 people (20 peoples for area $>85 \mathrm{dBA}$ and 16 people in area $\leq 85 \mathrm{dBA}$ ). Samples were taken using stratified random sampling technique, so that the sample was obtained by 25 people. The research result shows that the noise intensity in an area of 90,17 dBA STMC (southern area) and 89,67 dBA (northern area). The intensity of the SHE area of 62,57 dBA as well as the main office area of 60,97 dBA. Results of the analysis of changes in systolic blood pressure before and after working in the area STMC shows that the value of $p=0,001<0,05$ and the SHE area and main office showed that the value of $p=1,000>0,05$. Results of the analysis of changes in diastolic blood pressure before and after the work show that the value of $p=0,014<0,05$ and the SHE area and main office showed that the value of $p=1,000>0,05$. The conclusion was that there are differences in systolic and diastolic blood pressure before and after work on workers exposed to noise in the area STMC and there was no difference in systolic and diastolic blood pressure before and after work on workers exposed to noise in the SHE area and the main office.
\end{abstract}

Keywords: noise, noise exposure, blood pressure.

\section{ABSTRAK}

Tingginya intensitas kebisingan yang terjadi pada area kerja akan menimbulkan gangguan kesehatan seperti perubahan tekanan darah dan ganguan pendengaran. Penelitian ini merupakan penelitian observasional dengan desain penelitian kohort. Populasi penelitian ini diambil sesuai dengan syarat inklusi yang telah ditentukan, sehingga diperoleh populasinya 36 orang (20 orang pada area $>85$ dBA dan 16 orang di area $\leq 85 \mathrm{dBA}$ ). Sampel diambil dengan menggunakan teknik stratified random sampling, sehingga sampel di peroleh sebesar 25 orang. Hasil penelitian terlihat bahwa intensitas kebisingan di area STMC sebesar 90,17 dBA (area selatan) dan 89,67 dBA (area utara). Intensitas pada area SHE sebesar 62,57 dBA serta pada area main office sebesar 60,97 dBA. Hasil analisis perubahan tekanan darah sistole sebelum dan setelah bekerja di area STMC menunjukkan bahwa nilai $p=0,001<0,05$ serta pada area SHE dan main office menunjukkan bahwa nilai $p=1,000>0,05$. Hasil analisis perubahan tekanan darah diastole sebelum dan setelah bekerja menunjukkan bahwa nilai $p=0,014<0,05$ serta pada area SHE dan main office menunjukkan bahwa nilai $p=1,000>$ 0,05. Kesimpulannya adalah terdapat perbedaan tekanan darah sistole dan diastole sebelum dan setelah bekerja pada pekerja yang terpapar bising di area STMC serta tidak ada perbedaan tekanan darah sistole dan diastole sebelum dan setelah bekerja pada pekerja yang terpapar bising di area SHE dan main office.

Kata kunci: kebisingan, paparan bising, tekanan darah.

\section{PENDAHULUAN}

Dewasa ini teknologi mengalami kemajuan yang sangat pesat. Kamajuan teknologi seperti ini membuat penggunaan mesin pada industri mengalami peningkatan sesuai dengan kebutuhan industri tersebut. Namun, seiringnya peningkatan kebutuhan teknologi tersebut jika tidak diiringi dengan kontrol atau pengecekan pada mesin, akan menimbulkan masalah, hal ini disebabkan terdapat beberapa mesin yang menimbulkan suara yang keras atau bising. Masalah yang dapat terjadi diantaranya mengganggu kenyamanan dan kesehatan pekerja (Setiyanto, 2013)

Kebisingan merupakan segala jenis suara atau bunyi yang tidak dikehendaki. Kebisingan biasanya muncul karena adanya beberapa alat yang ada di industri terutama pada proses produksi, sebab pada proses produksi terdapat beberapa mesin yang menimbulkan suara berisik. Timbulnya suatu kebisingan ini dapat menimbulkan beberapa masalah, salah satunya seperti masalah pendengaran pada pekerja (Suma'mur, 2009).

Gangguan akibat kebisingan terdiri dari dua macam antara lain gangguan auditory dan non auditory. Salah satu gangguan auditory akibat tingginya intensitas kebisingan adalah ketulian sementara ataupun permanen pada pekerja yang bekerja di lingkungan dengan intensitas kebisingan yang tinggi. Namun, jika pekerja terpapar secara terus menerus dalam jangka waktu yang lama akan dapat merusak organ korti (Harrington, 2003). Gangguan non auditory atau gangguan bukan pendengaran salah satunya seperti gangguan berkomunikasi, sebab dengan adanya suara bising dan berisik akan mengakibatkan gangguan bicara secara 
langsung. Gangguan tersebut membuat para pekerja harus berteriak untuk bisa berkomunikasi dengan rekan kerjanya. Namun, terdapat pula gangguan komunikasi yang tidak langsung misalnya yaitu saat menerima telepon dari seseorang (Suma'mur, 2009).

Kebisingan merupakan salah satu gangguan yang diakibatkan oleh suara yang muncul dan tidak dikehendaki seseorang. Hal ini menunjukkan bahwa kebisingan merupaka masalah yang bersifat psikososial. Masalah seperti ini apabila datang secara berulang terhadap pekerja yang terpapar, sehingga menyebabkan terjadinya perubahan tekanan darah. Selain itu stress juga merupakan salah satu dampak dari paparan kebisingan. Hal tersebut dapat menimbulkan kelabilan psikologis pekerja seperti mudah marah. Sehingga munculnya stress akibat paparan kebisingan secara terus menerus memicu pelepasan hormon seperti kortisol, adrenalin serta noradrenalin yang pada akhirnya akan menimbulkan masalah lain salah satunya seperti perubahan tekanan darah dan frekuensi detak jantung (Tambunan, 2009).

Davis (1978) menjelaskan bahwa intensitass kebisingan yang terdapat pada area kerja merupakan salah satu masalah utama yang perli di perhatikan. Sebab, masalah kesisingan yang melebihi $85 \mathrm{dBA}$ dapat menimbulkan masalah pada pekerja terutama masalah kesehatan. Selain itu juga dapat di perkirakan lebih dari tujuh juta orang yang bekerja dalam industri atau perusahan telah terpapar bising yang melebihi nilai ambang batas.

Intensitas bising yang melebihi NAB merupakan salah satu masalah yang dapat mengganggu fungsi tubuh manusia. Gangguan tersebut seperti peningkatan sistem kardiovaskuler yang mengebabkan terjadinya peningkatan tekanan darah sistole dan tekanan darah diastole. Mekanisme timbulnya perubahan tekanan darah yakni akibat dari tingginya intensitas kebisingan tersebut dapat mengakibatkan ketidakstabilan hormon epinerin, non-epinerin dan kortisol tubuh yang mengakibatkan terjadinya perubahan irama jantung dan tekanan darah (Hidayat, 2004).

Menurut peraturan yang tercantum di PERMENAKERTRANS nomor 13 tahun 2011 tantang "nilai ambang batas faktor fisika dan faktor kimia di tempat kerja" yang tercantum dalam BAB II pasal 5 menjelaskan bahwa setiap tenaga kerja hanya boleh terpapar bising sebesar 85 dBA selama 8 jam kerja perhari. Jika seorang pekerja mengalami paparan melebihi NAB tersebut maka pekerja akan mengalami gangguan kesehatan seperti gangguan pendengaran atau perubahan tekanan darah (Tambunan, 2005).

Tingginya intensitas kebisingan yang terjadi pada area kerja akan menimbulkan gangguan kesehatan salah satunya adalah perubahan frekuensi detak jantung. Hal lain juga bisa terjadi seperti gangguan tidur, perubahan tekanan darah dan gangguan refleks (Soeripto, 2008).

Berdasarkan studi pendahuluan yang dilakukan di PT $\mathrm{X}$ yang merupakan industri paku terbesar di Indonesia menujukkan bahwa terdapat beberapa titik area di PT X yang memiliki intensitas kebisingan tinggi. Salah satunya adalah area produksi dengan intensitas kebisingan sebesar $95 \mathrm{dBA}$.
PT X juga mempekerjakan puluhan pekerja di area tersebut dengan rentang waktu yang cukup lama yakni 8 jam kerja perhari. Hal ini menunjukkan bahwa situasi tersebut tidak sesuai dengan PERMENAKERTRANS nomor 13 tahun 2011.

Selain itu juga berdasarkan keterangan dari salah satu staff SHE (Safety Health and Evironment) menyatakan bahwa sering terjadi gangguan atau masalah pada pekerja yang terpapar bising seperti gangguan komunikasi, gangguan pendegaran serta gangguan emosional pekerja. Hal tersebut juga diungkapkan Haringtonl, (2003) bahwa intensitas kebisingan yang tinggi dapat menimbulkan gangguan pada seseorang seperti psikososial dan psikomotor ringan.

Berdasarkan keteranga dokter dari industri PT X tersebut menyatakan bahwa pernah ada pekerja yang mengalami pingsan saat bekerja. Setelah dilakukan pemeriksaan pemerikasaan diketahui bahwa pekerja mengalami hipertensi. Namun, dokter tersebut tidak bisa memastikan penyebab kejadian tersebut akibat bising sebab terdapat beberapa faktor lain. Tetapi menurut Tambunan (2005) bahwa seseorang yang pengalami paparan kebisingan dalam jangka waktu lama seseorang tersebut dapat mengalami hipertensi.

Penelitian yang dilakukan oleh Sinaga (2013) pada operator di pabrik Ammonia IB PT Pupuk Sriwidjaja Pelembang menyebutkan bahwa terdapat hubungan yang signifikan antara intensitas kebisngan terhadap perubahan tekanan darah sistole dan tekanan darah diastole. Selain itu juga pada penelitian ini menyebutkan ada hubungan pemakaian alat pelindung telinga dengan perubahan tekanan darah sistole dan tekanan darah diastole.

Kebisingan yang mencapai $95 \mathrm{dBA}$ ini merupakan masalah yang akan diteliti. Penelitian ini akan dilakukan di area lingkungan PT X. Hal ini disebabkan karena PT X memiliki puluhan pekerja yang terpapar bising. Paparan yang dialami pekerja selama 8 jam kerja perhari. Berdasarkan hasil tersebut dilakukan perumusan masalah penelitian yakni apakah ada perbedaan tekanan darah (sistole dan diastole) sebelum dan setelah bekerja pada pekerja yang terpapar bising di PT X.

Tujuan penelitian ini adalah untuk menganalisis perbedaan tekanan darah (sistole dan diastole), sebelum dan setelah bekerja pada pekerja yang terpapar bising di PT X.

\section{METODE}

Berdasarkan jenisnya penelitian ini merupakan penelitian observasional sebab penelitian ini dilakukan menggambarkan keadaan sebenarnya yang terjadi di lapangan. Berdasarkan desain penelitian ini merupakan desain penelitian kohort, sebab faktor resiko diidentifikasi terlebih dahulu kemudian efeknya diikuti secara prospektif. Berdasarkan hasil analisisnya penelitian ini tergolong penelitian analitik.

Penelitian ini dilakukan pada pekerja yang bekerja di PT X. Waktu pengukuran dan pengambilan data dilaksanakan pada bulan Maret 2015.

Populasi pekerja yang diambil merupakan pekerja yang telah memenuhi syarat inklusi. Syarat inklusi tersebut 
diantaranya (1) jenis kelamin laki-laki, (2) umur diantara 20 meliputi rekap data perusahan seperti buku, dokumen serta hingga 50 tahun, (3) tidak mengkonsumsi alkohol, (4) tidak peraturan atau kebijakan di PT X.

memiliki riwayat penyakit seperti penyakit jantung dan

Pengolahan data kuesioner pada penelitian ini hipertensi dan (5) orang yang bekerja di PT X. Sehingga menggunakan tiga tahapan yang meliputi editing populasi didapatkan sebesar 36 orang. Pengambilan sampel (pengecekan data), coding (pemberian kode pada jawaban) menggunakan rumus stratified random sampling, sebab dan menganalisis dengan menggunakan aplikasi komputer. populasi bersifat heterogen sehingga populasi tersebut Berdasarkan Suma'mur (2009) menuturkan bahwa untuk dilakukan pengelompokan sesuai strata sehingga bersifat menganalisis nilai intensitas kebisingan dapat dilakukan homogen.

Pengelompokan stata tersebut berdasarkan tingkat intesitas kebisingan. Sehingga populasi menjadi 2 (dua) kelompok yaitu area STMC (intensitas bising $>85 \mathrm{dBA}$ ) dan kantor SHE dan main office (intensitas bising $\leq 85 \mathrm{dBA}$ ). Berikut rumus sampling yang digunakan (Kuntoro, 2009).

$$
n=\frac{\sum_{i=1}^{L} N i . \text { pi.qi/wi }}{N^{2} . D+\sum_{i=1}^{L} \text { Ni.pi.qi }}
$$

teknik analisis data menggunakan rumus $\mathrm{Lp}=10 \log \left(\frac{\mathrm{Pn}^{2}}{\mathrm{po}_{\mathrm{o}}^{2}}\right)$ untuk analisis intensitas kebisingan sedangkan analisis perubahan tekanan darah sistole dan tekanan darah diastole dilakukan pengujian menggunakan uji statistik yaitu wilcoxon signed rank test.

HASIL

\section{Gambaran Umum PT X}

PT X telah mempekerjakan \pm 300 tenaga kerja dengan

Setelah semua komponen jumlah populasi $(\mathrm{N})$, proporsi $(\mathrm{p}), \mathrm{q}=1-\mathrm{p}$ serta nilai $\mathrm{D}=$ $\frac{B^{2}}{4}=\frac{0,05^{2}}{4}=0,000625$ sehingga didapatkan sampel total 25 dengan rincian 15 pekerja dari area STMC (Straightening Mechine) serta 10 pekerja dari area SHE dan main office.

Variabel penelitian ini yaitu intensitas kebisingan, tekanan darah sistole, tekanan darah diastole, umur dan masa kerja individu.

Teknik dan instrumen pengambilan data pada penelitian ini terdiri dari dua macam. (1) Data primer yang meliputi pengukuran langsung intensitas kebisingan dengan menggunakan sound level meter, pengukuran langsung tekanan darah menggunakan spygmomanometer serta data lain yang diperoleh dari koesioner. (2) Data sekunder yang

100 tenaga kerja sebagai staff tetap dan 200 tenaga kerja yang berasal dari pekerja borongan. PT X ini tidak ada shiff kerja atau pergantian shiff, pada pekerja sebagai staff tetap bekerja pada pukul 09.00-18.00 WIB sedangkan pada pekerja borongan pada area produksi jadwal kerjanya pada pukul 08.00-17.00 WIB dan khusus pada pekerja borongan sebagai banding bekerja pada pukul 07.00-13.00 WIB. Setiap waktu kerja tersebut terdapat selang satu jam untuk pekerja beristirahat. Seluruh pekerja tersebut diperkerjakan pada hari Senin hingga hari Jum'at.

\section{Karakteristik Pekerja}

Variabel karakteristik pekerja yang diambil dalam penelitian ini adalah umur dan masa kerja. Distribusi karakteristik tersebut dapat dilihat pada tabel 1 dan tabel 2 berikut.

Tabel 1. Distribusi Karakteristik Pekerja Menurut Umur di PT X Tahun 2015

\begin{tabular}{ccccc}
\hline \multirow{2}{*}{ Kelompok Umur } & \multicolumn{5}{c}{ Tempat Kerja } \\
\cline { 2 - 5 } & \multicolumn{2}{c}{ STMC } & \multicolumn{2}{c}{ SHE dan Main Office } \\
\cline { 2 - 5 } & $\mathbf{n}$ & $\mathbf{\%}$ & $\mathbf{N}$ & $\mathbf{\%}$ \\
\hline $21-30$ Tahun & 0 & 0 & 4 & 40 \\
\hline $31-40$ Tahun & 7 & 46,7 & 5 & 10 \\
\hline $41-50$ Tahun & 8 & 53,3 & 1 & $\mathbf{1 0 0}$ \\
\hline Total & $\mathbf{1 5}$ & $\mathbf{1 0 0}$ & $\mathbf{1 0}$ &
\end{tabular}

Sumber: data primer

Berdasarkan hasil dari analisis distribusi yang SHE dan Main Office mayoritas pada kelompok umur mulai ditunjukkan oleh tabel 1 dapat dilihat bahwa umur pekerja dari 31 tahun hingga 40 tahun dengan prosentase sebesar yang bekerja di area STMC mayoritas pada kelompok umur 50\% (5 orang). Umur pekerja yang paling rendah adalah mulai dari 41 tahun hingga 50 tahun dengan prosentase umur 25 tahun berjumlah satu orang dan umur pekerja sebesar 53,3\% (8 orang). Pekerja yang bekerja di area kantor tertinggi adalah 50 tahun berjumlah satu orang. 
Tabel 2. Distribusi Karakteristik Pekerja Menurut Masa Kerja di PT X Tahun 2015

\begin{tabular}{ccccc}
\hline \multirow{2}{*}{ Masa Kerja } & \multicolumn{3}{c}{ Tempat Kerja } \\
\cline { 2 - 5 } & $\mathbf{n}$ & $\boldsymbol{N}$ & $\mathbf{N}$ SHE dan Main Office \\
\cline { 2 - 5 } & 2 & 13,3 & 0 & $\%$ \\
\hline$\leq 2$ thn & 4 & 26,7 & 3 & 0 \\
\hline $3-4$ thn & 9 & 60 & 7 & 70 \\
\hline$\geq 5$ thn & $\mathbf{1 5}$ & $\mathbf{1 0 0}$ & $\mathbf{1 0}$ & $\mathbf{1 0 0}$
\end{tabular}

Sumber: data primer

Berdasarkan hasil distribusi yang diperoleh dari Office juga bekerja selama lebih dari 5 tahun sebesar $70 \%$ koesioner mengenai masa kerja pekerja yang disajikan pada atau 7 orang. Tabel 2 juga menunjukkan bahwa tidak ada satu tabel 2 terlihat bahwa pekerja yang bekerja di area STMC orang pun yang baru bekerja selama kurang dari sama dengan mayoritas telah bekerja selama lebih dari sama dengan 52 tahun Hal ini menunjukkan bahwa pekerja yang ada di PT tahun dengan prosentase sebesar $60 \%$ yakni 9 orang. X tersebut merupakan pekerja lama.

Mayoritas pekerja yang bekerja di kator SHE dan Main

\section{Nilai Lp Intensitas Kebisingan}

Perhitungan intensitas kebisingan pada penelitian ini menggunakan tekanan suara. Berikut ini adalah tabel dilakukan analisis dengan pengukuran intensitas kebisingannya.

Tabel 3. Hasil Pengukuran Intensitas Kebisingan di Area PT X Tahun 2015

\begin{tabular}{|c|c|c|c|c|}
\hline \multirow[b]{2}{*}{ Nama Tempat } & \multicolumn{3}{|c|}{ Hasil Ukur } & \multirow[b]{2}{*}{ Rerata (Lp) } \\
\hline & I & II & III & \\
\hline Kantor SHE & 57 & 58 & 58,3 & 62,57 \\
\hline Main Office & 55 & 56.7 & 56,7 & 60,97 \\
\hline STMC selatan & 89,9 & 89,9 & 90,7 & 94,95 \\
\hline STMC utara & 90,7 & 89,2 & 89,1 & 94,5 \\
\hline
\end{tabular}

Sumber: data primer

Nilai kebisingan dapat diperoleh dengan melakukan bagian selatan sebesar 94,95 dBA dan STMC bagian utara pengkuran secara langsung pada area kerja. Pengukuran sebesar 94,5 dBA. intensitas kebisingan tersebut dilaksanakan pada bulan Maret hingga April 2015 pada area STMC serta Main Office dan kantor SHE di PT X. Pengukuran kebisingan dilakukan selama tiga menit, kemudian setiap menit dilakukan pencatatan sehingga didapatkan tiga nilai intensitas kebisingan pada setiap area. Peneliti melakukan pengukuran intensitas kebisingan dengan menggunakan alat yang bernama Sound Level Meter (SLM). Waktu pengukuran ini dilakukan mulai pukul 10.00-13.30 WIB. Hasil pengukuran intensitas kebisingan dapat dilihat pada tabel 3.

Setelah dilakukan pengukuran intensitas kebisingan bising maka hasil ukurnya selama tiga menit dapat dilihat pada tabel 3. Selanjutnya, hasil ukur intensitas kebisingan tersebut dilakukan perhitungan dengan menggunakan rumus Lp. Hasil hitung dengan menggunakan rumus Lp dapat dilihat pada tabel 3. Bedasarkan hasil yang ditunjukkan pada tabel 3 menjelaskan bahwa hasil ukurnya menunjukkan terdapat perbedaan yang cukup signifikan mengenai hasil pengukuran intensitas kebisingan. Area kantor SHE menunjukan nilai intensitas kebisingan sebesar 62,57 dBA dan pada area main office sebesar 60,97 dBA, area STMC
Perbedaan hasil hitung Lp intensitas bising pada tabel 3 dikarenakan pada area kantor SHE dan main office tidak terdapat mesin produksi atau mesin lain yang mengeluarkan suara keras, sedangkan pada area STMC bagian selatan dan utara terdapat mesin produksi yang mengeluarkan suara yang sangat keras sehingga hal tersebut membuat intensitas bising menjadi tinggi.

\section{Pengukuran Tekanan Darah}

Pengkuran tekanan darah pada penelitian ini dilakukan dua kali waktu yakni pada saat pekerja belum beraktifitas atau belum bekerja dan setelah bekerja. Pengukuran tekanan darah tersebut dua kali waktu, hal ini bertujuan agar dapat melihat perbedaan tekanan darah sistole dan diastole sebelum dan setelah bekerja pada pekerja yang terpapar bising di PT $X$. Pengukuran tekanan darah ini dilakukan dengan menggunakan alat yang bernama spygmomanometer.

Menurut Irwandi (2013) menyebutkan bahwa pengukuran tekanan darah seseorang harus sesuai dengan step atau cara yang benar, hal ini bertujuan agar mengurangi terjadinya bias pada saat pengukuran tekanan darah (sistole dan diastole). Berikut cara dalam melakukan pengukuran 
tekanan darah seseorang menggunakan spygmomanometer antara lain : (1) Pasang manset pada bagian lengan atas dengan jarak kurang lebih 2 sampai 3 jari dari batas bawah menset. (2) Letakkan stetoskop pada bagian atas arteri brakialis. (3) Raba pulsasi pada bagian arteri radialis (terdapat pada pergelangan tangan). (4) Pompa manset hingga mencapai $30 \mathrm{mmHg}$ setelah pulsasi arteri radialis menghilang. (5) Buka katup manset dengan perlahan, kemudian tekanan dibiarkan turun. (6) Catat bunyi pertama yang didengar pada alat stetoskop (tekanan sistole). (7) Catat bunyi yang terakhir terdengar pada alat stetoskop (tekanan B diastole). (8) Turunkan tekanan pada manset hingga mencapai $0 \mathrm{mmHg}$ lalu lepaskan manset dari lengan bagian atas.
Dalam pengukuran tekanan darah sistole dan tekanan darah diastole peneliti melakukan pengukuran dengan bantuan dokter peruhatan PT X tersebut. Peneliti melakukan pengukuran pada pekerja yang berapa di area STMC, sedangkan dokter perusahan melakukan pengukuran pada pekerja yang bekerja di area SHE dan main office. Setelah dilakukan pengukuran maka nilai tekanan darah sistole dan tekanan darah diastole sebelum dan setelah bekerja pada pekerja yang terpapar bising bisa diketahui. Hasil pengukuran tekanan darah tersebut dapat dilihat pada tabel 4 berikut. Berdasarkan tabel 4 juga bis dilitahat perubahan tekanan darah sistole dan tekanan darah diastole.

Tabel 4. Hasil Pengukuran Tekanan Darah Sistole dan Diastole pada Pekerja di PT X Tahun 2015

\begin{tabular}{|c|c|c|c|c|c|c|c|}
\hline \multirow{2}{*}{$\begin{array}{l}\text { No } \\
\text { Res. }\end{array}$} & \multirow[b]{2}{*}{ Tempat kerja } & \multicolumn{3}{|c|}{ Tekanan Darah Sistole } & \multicolumn{3}{|c|}{ Tekanan Darah Diastole } \\
\hline & & $\begin{array}{l}\text { Sebelum } \\
\text { Bekerja }\end{array}$ & $\begin{array}{l}\text { Setelah } \\
\text { Bekerja }\end{array}$ & Perubahan & $\begin{array}{l}\text { Sebelum } \\
\text { Bekerja }\end{array}$ & $\begin{array}{l}\text { Setelah } \\
\text { Bekerja }\end{array}$ & Perubahan \\
\hline 1 & STMC & 120 & 130 & Naik & 80 & 90 & Naik \\
\hline 2 & STMC & 120 & 130 & Naik & 80 & 90 & Naik \\
\hline 3 & STMC & 110 & 118 & Naik & 80 & 80 & Tetap \\
\hline 4 & STMC & 120 & 130 & Naik & 80 & 90 & Naik \\
\hline 5 & STMC & 122 & 130 & Naik & 80 & 90 & Naik \\
\hline 6 & STMC & 110 & 120 & Naik & 80 & 80 & Tetap \\
\hline 7 & STMC & 110 & 120 & Naik & 80 & 80 & Tetap \\
\hline 8 & STMC & 110 & 120 & Naik & 80 & 80 & Tetap \\
\hline 9 & STMC & 120 & 126 & Naik & 80 & 80 & Tetap \\
\hline 10 & STMC & 110 & 120 & Naik & 80 & 80 & Tetap \\
\hline 11 & STMC & 120 & 132 & Naik & 80 & 90 & Naik \\
\hline 12 & STMC & 120 & 128 & Naik & 80 & 80 & Tetap \\
\hline 13 & STMC & 120 & 122 & Naik & 80 & 80 & Tetap \\
\hline 14 & STMC & 120 & 122 & Naik & 80 & 80 & Tetap \\
\hline 15 & STMC & 120 & 130 & Naik & 80 & 90 & Naik \\
\hline 16 & Main Office dan SHE & 110 & 110 & Tetap & 80 & 80 & Tetap \\
\hline 17 & Main Office dan SHE & 110 & 110 & Tetap & 80 & 80 & Tetap \\
\hline 18 & Main Office dan SHE & 130 & 130 & Tetap & 80 & 80 & Tetap \\
\hline 19 & Main Office dan SHE & 120 & 120 & Tetap & 90 & 90 & Tetap \\
\hline 20 & Main Office dan SHE & 110 & 110 & Tetap & 80 & 80 & Tetap \\
\hline 21 & Main Office dan SHE & 120 & 120 & Tetap & 80 & 80 & Tetap \\
\hline 22 & Main Office dan SHE & 120 & 120 & Tetap & 80 & 80 & Tetap \\
\hline 23 & Main Office dan SHE & 110 & 110 & Tetap & 80 & 80 & Tetap \\
\hline 24 & Main Office dan SHE & 120 & 120 & Tetap & 80 & 80 & Tetap \\
\hline 25 & Main Office dan SHE & 130 & 130 & Tetap & 90 & 90 & Tetap \\
\hline
\end{tabular}

Sumber: data primer

Berdasarkan hasil distribusi pada tabel 4 menjelaskan tersebut dibuktikan dengan adanya 15 orang pekerja pada terdapat perbedaan yang sangat signifikan mengenai area STMC mengalami perubahan kenaikan tekanan darah perubahan tekanan darah sistole pada saat sebelum dan sistole, sedangkan pada area SHE dan main office tidak setelah bekerja pada pekerja yang terpapar bising. Hal 
terdapat satu orang pekerja yang mengalami perubahan tekanan darah sistole.

Berdasarkan hasil distribusi pada tabel 4 menjelaskan terdapat perbedaan yang cukup signifikan mengenai perubahan tekanan darah diastole pada saat sebelum dan setelah bekerja pada pekerja yang terpapar bising, yakni pada area STMC reponden hanya mengalami perubahan kenaikan tekanan darah diastole sebesar 6 orang pekerja. Semantara itu, pada area kantor SHE dan main office seluruh pekerja tidak mengalami perubahan tekanan darah diastole pada pengukuran sebelum dan setelah bekerja.

\section{Perbedaan Tekanan Darah Area STMC}

Setelah dilakukan analisis variabel dengan menggunakan uji statistik wilcoxon signed ranks test untuk pekerja pada area STMC. Bedasarkan hasil analisis yang telah dilakukan maka dapat dilihat ada atau tidaknya perbedaan tekanan darah sebelum dan setelah bekerja pada pekerja yang terpapar bising.

Nilai signifikansi perubahan tekanan darah sistole sebelum dan setelah bekerja pada pekerja yang terpapar bising adalah $\mathrm{p}=0,001<0,05$ sehingga bermakna bahwa ada perbedaan tekanan darah sistole sebelum dan setelah bekerja pada pekerja di area STMC. Nilai signifikansi perubahan tekanan darah diastole sebelum dan setelah bekerja pada pekerja yang terpapar bising yaitu $\mathrm{p}=0,014<0,05$ sehingga bermakna bahwa ada perbedaan tekanan darah diastole sebelum dan setelah bekerja pada pekerja di area STMC.

\section{Perbedaan Tekanan Darah di Area SHE dan Main Office}

Setelah dilakukan analisis variabel memakai uji statistik wilcoxon signed ranks test untuk pekerja pada area SHE dan main office. Bedasarkan hasil analisis yang telah dilakukan maka dapat dilihat ada atau tidaknya perbedaan tekanan darah dan denyut nadi sebelum dan setelah bekerja pada pekerja yang terpapar bising.

Nilai signifikansi perubahan tekanan darah sistole sebelum dan setelah bekerja adalah $\mathrm{p}=1,000>0,05$ sehingga bermakna bahwa tidak ada perbedaan tekanan darah sistole sebelum dan setelah bekerja pada pekerja di kantor SHE dan main office. Nilai signifikansi perubahan tekanan darah diastole sebelum dan setelah bekerja adalah $\mathrm{p}=1,000>0,05$ sehingga bermakna bahwa tidak ada perbedaan tekanan darah diastole sebelum dan setelah bekerja pada pekerja di kantor SHE dan main office.

\section{PEMBAHASAN}

Suara yang didengar sebagai rangsangan yang diterima oleh sel saraf pada telinga oleh gelombang longitudinal yang muncul akibat getaran dari sumber suara dan gelombang yang merambat melalui udara, sehingga suatu suara tersebut tidak dikehendaki kehadirannya atau kemunculannya, sebab hal tersebut dapat mengakibatkan seseorang merasa terganggu dan dapat membahayakan kesehatan seseorang (Anizar, 2009).

Bedasarkan tabel 3 pengukuran intensitas kebisingan di area STMC didapatkan bahwa nilai intensitas kebisingan tersebut melebihi $85 \mathrm{dBA}$. Hal ini menjadikan area tersebut sebagai kelompok 1 yang terpapar intensitas bising tinggi. Kebesingan yang telah terjadi di area PT X merupakan jenis kebisingan yang menetap dan bekelanjuatan secara terus menerus tanpa terputus dengan spektrum frekuensi yang melebar akibat mesin produksi yang dioperasikan. Hal ini mengakibatkan munculnyaberbagai gangguan seperti gangguan kesehatan.

Berdasarkan hasil hitung nilai Lp yang di sajikan pada tabel 3maka terlihat bahwa intensitas kebisingan yang ada di area STMC telah melebihi Nilai Ambang Batas (NAB). Hal tersebut tidak sesuai dengan Peraturan Menteri Tenaga Kerja dan Transmigrasi Republik Indonesia Nomor 13/MEN/X/2011 tentang "Nilai Ambang Batas Faktor Fisika dan Faktor Kimia di Tempat Kerja pada BAB II pasal 5 ayat 1 dijelaskan bahwa NAB kebisingan ditetapkan sebesar 85 dBA. Hal ini disebabkan bebarapa faktor. Berdasarkan penelitian yang dilakukan faktor tersebut disebabkan oleh : (1) Ada lebih dari 10 mesin produksi yang selalu beropersi menimbulkan suara yang nyaring atau berisik. (2) Bising juga dapat di peroleh dari luar sebab area STMC merupakan area terbuka, sehingga kebisingan dari luar area STMC dapat mempengaruhi intensitas kebesingan pada area tersebut.

Berdasarkan hasil pengukuran yang pada tabel 3 menunjukkan bahwa pada area kantor SHE dan main office bila dibandingkan dengan peraturan PERMENAKERTRANS nomor 13 tahun 2011 maka nilai intensitas kebisingan pada area tersebut masih dibawah NAB. Berdasarkan saat pengukuran, hal tersebut disebabkan karena faktor yang mempengaruhinya meliputi: (1) keadaan kantor merupakan ruangan tertutup dengan memiliki pintu yang di design agar selalu menutup secara otomatis ketika pintu tersebut dibuka, sehingga kemungkinan kecil area tersebut mendapatkan suara bising dari luar kantor. (2) Tidak ada mesin yang menimbulkan bunyi nyaring, area tersebut hanya dilengkapi oleh AC dan mesin printing. Namun begitu tidak berpengaruh signifikan terhadap intensitas kebisingan.

Berdasarkan waktu paparan yang diatur dalam Peraturan Menteri Tenaga Kerja dan Transmigrasi Nomor 13/MEN/X/2011 tentang "Nilai Ambang Batas Faktor Fisika dan Faktor Kimia di Tempat Kerja" pada pasal 5 ayat 2 menyebutkan bahwa waktu paparan telah tercantum dalam Lampiran 1 nomor 2 peraturan menteri tersebut. Waktu paparan pada intensitas kebisingan 85 dBA maksimal selama 8 jam kerja perhari. Jika dilihat pada peraturan menteri tersebut maka waktu paparan pekerja pada area STMC seharus tidak lebih dari 2 jam kerja perhari, namun kenyataannya pekerja terpapar selama 8 jam kerja perhari dengan intensitas kebisingan yang tinggi seperti yang ditujukkan pada tabel 3 pada pembahasan sebelumnya. Area kantor SHE dan main office telah sesuai dengan waktu paparan yang telah diatur dalam peraturan menteri tersebut yakni pekerja hanya terpapar selama 8 jam kerja perhari dengan intensitas kebisingan dibawah $85 \mathrm{dBA}$.

Intensitas kebisingan yang tinggi tersebut dapat terjadi karena banyaknya mesin produksi yang dioperasikan sehingga menimbulkan suara yang nyaring. Hal ini dikarenakan mesin produksi tersebut mengalami benturan antar logam dan besi. Tingginya intensitas kebisingan yang 
terjadi berdampak pada perubahan tekanan darah (sistole dan diastole) serta perubahan denyut nadi.

Berdasarkan hasil uji statistik pada tekanan darah sistole dan diastole yang dilakukan pada pekerja di area STMC dengan memakai uji wilcoxon signed rank test. Hasil tersebut menunjukkan bahwa ada perbedaan tekanan darah sistole dan diastole sebelum dan setelah bekerja pada pekerja yang terpapar bising di area STMC. Uji wilcoxon signed rank test yang digunakan pada pekerja di kantor SHE dan main office diperoleh bahwa tidak ada perbedaan tekanan darah sistole dan diastole sebelum dan setelah bekerja pada pekerja yang terpapar bising di kantor SHE dan main office.

Berdasarkan hasil penelitian yang dilakukan, diketahui bahwa terdapat perbedaan yang signifikan antara intensitas kebisingan tempat kerja dengan kejadian perubahan tekanan darah sistole dan diastole sebelum dan setelah bekerja pada pekerja yang tepapar bising di PT X. Hasil penelitian tersebut didukung oleh beberapa studi, salah satunya penelitian yang dilakukan oleh Nurdiansyah (2013) di PT. Kereta Api Indonesia (PERSERO) UPT crew Surabaya Pasarturi menjelaskan bahwa ada pengaruh intensitas kebisingan terhadap perubahan tekanan darah sistole dan diastole.

Penelitian yang dilakukan di PT PJB Gresik didapatkan bahwa ada pengaruh intensitas kebisingan terhadap kenaikan tekanan darah. Penelitian ini menyebutkan bahwa resiko pekerja yang terpapar bising akan mengalami kenaikan tekanan darah 1,647 kali daripada pekerja yang tidak terpapar bising. Hal ini juga ditunjukkan lebih dari 70 persen pekerja mengalami kenaikan tekanan darah dari saat sebelum dan setelah terpapar bising (Paramita, 2012).

Penelitian yang dilakukan di area kerja PT. Semen Tonasa didapatkan bahwa lingkungan kerja dengan teknik unloading crane, cruser batu kapur unit IV, raw mill (unit II, III dan IV), coal mill, sement mill dan packing plant memiliki kebisingan yang tinggi yang mengakibatkan para pekerja mengalami kenaikan tekanan darah. Rata-rata kenaikan tekanan darah sistoliknya yaitu 19,2 $\mathrm{mmHg}$ dan diastoliknya yaitu $6,8 \mathrm{mmHg}$. Pengukuran tekanan darah dilakukan sebelum dan sesudah bekerja (Babba, 2007).

Berdasarkan penelitian Susanti (2013) pada PT Iskandar Indah Printing Textile Surakarta menunjukkan bahwa nilai kebisangan pada industri tersebut memiliki rerata sebesar 100,27 dBA. Hasil analisis perubahan tekanan darah juga menunjukkan bahwa nilai $\mathrm{p}=0,000$, dan disimpulkan terdapat perbedaan tekanan darah sebelum dan sesudah kerja antara yang memakai ear plug dan yang tidak memakai ear plug.

Penelitian yang dilakukan Hartati (2011) pada PT Indo Acidatama pada unit boiler batubata menunjukkan bahwa terdapat perbedaan yang bermakna antara tekanan darah sistole pada pekerja sebelum dan sesudah terpapar bising yang melebihi NAB. Selain itu juga menunjukkan bahwa terdapat perbedaan yang bermakna antara tekanan darah diastole pada pekerja sebelum dan sesudah terpapar bising yang melebihi NAB.

Bedasarkan penelitian ini juga diketahui bahwa demi menjamin kesehatan para pekerja, perusahaan melalui dokter perusahan telah melakukan pemeriksaan kesehatan kepada setiap pekerjanya. Pemeriksaan kesehatan ini diharapkan dapat mencegah bahaya yang telah diperkirakaan sebelumnya seperti gangguan pendengaran maupun peningkatan tekanan darah dan denyut nadi. Munurut PERMENAKERTRANS Nomor Per.02/MEN/1980 tentang "pemeriksaan kesehatan tenaga kerja dalam penyelenggaraan keselamatan kerja" pasal 2 ayat 2 dijelaskan bahwa setiap perusahaan harus melakukan pemerikasaan kesehatan.

Berdasarkan penelitian yang telah dilakukan, terlihat bahwa waktu paparan yang diterima oleh pekerja tidak sesuai dengan waktu paparan yang seharusnya diterima sebagaimana yang tercantum dalam peraturan menteri. Paparan yang dialami oleh pekerja PT X yang cukup lama mengakibatkan timbulnya masalah kesehetan seperti perubahan tekanan darah sistole dan diastole.

Berdasarkan hasil penelitian, terlihat bahwa waktu paparan yang diterima pekerja tidak sesuai dengan waktu paparan yang seharusnya diterima sebagaimana yang tercantum dalam peraturan menteri. Tingginya intensitas kebisingan mengakibatkan ketidakstabilan hormon stress seperti epinerin, non-epinerin dan kortisol tubuh yang mengakibatkan terjadi perubahan irama jantung dan tekanan darah. Kebisingan tersebut juga dapat mengakibatkan emosi seseorang manjadi tidak stabil, sehingga memicu jantung bekerja lebih keras dalam memompa darah ke seluruh tubuh.

Timbulnya stress akibat bising tersebut juga mengakibatkan bertambahnya hormon adrenalin. Kadar hormon adrenalin yang meningkat dapat menimbulkan perubahan tekanan darah dan detak jantung menjadi tidak stabil. Perubahan tekanan darah dan denyut nadi tersebut hanyalah bersifat sementara. Selain itu, saat tubuh melepaskan hormon adrenalin ke dalam sistem tubuh manusia, maka tubuh juga akan mengeluarkan hormon kortisol. Kadar kortisol pada tubuh yang tidak stabil akan menyebabkan tubuh menahan sodium (garam), hal tersebut dapat menyebabkan perubahan tekanan darah. Namun menurut Tambunan (2005) menjelaskan bahwa seorang pekerja yang terpapar bising dalam jangka waktu yang lama atau secara terus menerus akan mengakibatkan timbulnya penyakit hipertensi.

Berdasarkan penelitian ini didapatkan bahwa perusahan telah menyediakan alat pelindung diri (APD). Penyediaan APD ini dilakukan perusahan demi menjaga keselamatan pekerjanya dari bahaya akibat bising maupun non bising perusahaan telah menyediakan alat pelindung diri seperti safety helmet, sepatu safety, safety glass, masker dan sarung tangan.m Perusahaan juga menyediakan alat pelindung telinga. Alat pelindung telinga ini digunakan untuk mengurangi dampak yang di akibatkan oleh kebisingan yang tinggi. Jenis alat pelindung telinga yang di sediakan oleh perusahaan adalah ear plug. Penyediaan APD ini diatur dalam PERMENAKERTRANS nomor 8 tahun 2010 tentang alat pelindung diri pasal 2 ayat 1 menyebutkan bahwa "setiap perusahaan wajib menyediakan APD bagi pekerja di tempat kerja”. APD tersebut diberikan sesuai dengan potensi bahaya yang dialami pekerja. Pemberian alat pelindung diri ini bertujuan untuk mengurangi sisa dampak negatif yang dapat terjadi pada pekerja seperti masalah kesehatan. 
Selain penyedian APD sebagai pengendalian bahaya, perusahan seharusnya juga melakukan pengendalian secara teknik. Hal ini dikarenakan sumber bising terbesar dari mesin alat produksi. Mesin yang menimbulkan suara nyaring tersebut perlu dilakukakan pengendalian secara teknik. Salah satunya dengan cara memodifikasi alat mesin produksi dengan memasang dynamic dampers atau sejenis karet. Pemasangan dynamic dampers ini diletakkan pada bagian mesin yang mengalami benturan, sehingga diharapkan dengan pemasangan ini dapat mengurangi suara yang nyaring akibat benturan antar logam atau besi pada mesin produksi tersebut. Namun, pemasangan dynamic dampers tersebut hanya menghilangkan suara bising untuk sementara saja.

Selanjutnya dilakukan pemantauan intensitas kebisingan yang dilakukan dengan cara pungukuran kembali intensitas kebisingan pada area tersebut. Pemantauan tersebut sekurang-kurangnya dapat dilakukan selama satu tahun dua kali atau tiap enam bulan sekali. Hal ini bertujuan agar dapat mengontrol intensitas kebisingannya setiap tahun, sehingga kedepannya dapat dilakukan pencegahan secara dini dalam mengatasi dampak yang ditimbulkan.

Hal lain juga bisa dilakukakan salah satunya dengan cara mengurangi paparan bising pada pekerja. Pengendalian ini dapat dilakukan dengan cara mengurangi jam kerja dan atau melakukan program shift kerja. Namun kelemahan program tersebut adalah kelancaran dalam pelaksanaa program ini tergantung pada sistem pengawasan dan pekerjanya sendiri.

\section{KESIMPULAN}

Berdasarkan hasil penelitian, dapat disimpulkan yaitu : (1) Didapatkan nilai intensitas kebisingan rata-rata pada area STMC sebesar 94,95 dBA (area selatan) dan 94,5 dBA (area utara). Nilai intensitas kebisingan pada area kantor SHE sebesar 62,57 dBA dan main office sebesar 62,57 dBA. (2) Hasil analisis menunjukkan terdapat perbedaan tekanan darah sistole sebelum dan setelah bekerja pada pekerja yang terpapar bising di area STMC. Hasil lain juga menunjukkan bahwa tidak ada perbedaan tekanan darah sistole sebelum dan setelah bekerja pada pekerja yang terpapar bising di kantor SHE dan main office. (3) Hasil analisis menunjukkan terdapat perbedaan tekanan darah diastole sebelum dan setelah bekerja pada pekerja yang terpapar bising di area STMC. Hasil lain juga menunjukkan bahwa tidak ada perbedaan tekanan darah diastole sebelum dan setelah bekerja pada pekerja yang terpapar bising di kantor SHE dan main office.

Demi menjaga kesehatan pekerja, perusahan sebaiknya melakukan pemerikasaan kesehatan secara rutin yang bisa dikoordinasikan langsung pada dokter perusahan. Pelaksanaannya dapat dilakukan enam bulan sekali dengan harapan penyakit akibat kerja yang diakibatkan oleh bising di area kerja dapat dicegah sejak dini.

\section{DAFTAR PUSTAKA}

Anizar. 2009. Teknik Keselamatan dan Kesehatan Kerja Industri. Yogyakarta : Graha Ilmu
Babba, Jennie. 2007. Hubungan Intensitas Kebisingan di Lingkungan Kerja dengan Peningkatan Tekanan Darah. Tesis. Semarang : Universitas Diponegoro

Davis, Siverman. 1978. Hearing and deafness. New York : Holt, Rineheart and Winston

Harrington, Gill. 2003. Buku Saku Kesehatan Kerja. Edisi 3. Jakarta : Penerbit buku kedokteran EGC.

Hartati. 2011. Perbedaan Tekanan Darah Tenaga Kerja Sebelum dan Sesudah Terpapar Kebisingan Melebihi NAB di Unit Boiler Batubara PT Indo Acidatama Tbk Kemiri Kebakkramat Karanganyar. Skripsi. Surakarta : Universitas Sebelas Maret

Hidayat. 2005. Pengaruh Pemakaian APD Telinga Ear plug Terhadap perubahan tekana Darah Akibat Bising di Kecamatan Karanganyar Kabupaten Karanganyar. Skripsi. Semarang : Universitas Diponegoro

Kuntoro. 2009. Dasar Filosofis Metodologi Penelitian. Surabaya : Pustaka Melati

Nurdiansyah, C.W. 2013. Pengaruh Intensitas Kebisingan Lokomotif Terhadap Tekanan Darah Operator Lokomotif di PT KAI (PERSERO) UPT Crew Surabaya Pasarturi. Skripsi. Surabaya : Universitas Airlangga

Paramita, Dita Aisyah. 2012. Pengaruh Intensitas Kebisingan Terhadap Kenaikan Tekanan Darah Karyawan (Studi Pada Pelaksanaan Overhaul di PT. PJB Gresik). Skripsi. Surabaya : Universitas Airlangga

Peraturan Menteri Tenaga Kerja dan Transmigrasi R.I Nomor Per.13/Men/2011 Tentang NAB Faktor Fisika dan Faktor Kimia di Area Kerja" dalam BAB II Pasal 5

Peraturan Menteri Tenaga Kerja dan Transmigrasi R.I Nomor Per.08/Men/2010 Tentang Alat Pelindung Diri Pasal 2 Ayat 1

Peraturan Menteri Tenaga Kerja dan Transmigrasi R.I Nomor Per.02/MEN/1980 tentang Pemeriksaan Kesehatan Tenaga Kerja dalam Penyelenggaraan Keselamatan Kerja Pasal 2 Ayat 2

Setiyanto, Tri. 2013. Pengaruh Intensitas Kebisingan Terhadap Kenaikan Denyut Nadi pada Pekerja di PT PERTANI (PERSERO) Cabang Surakarta. Artikel. Surakarta : Universitas Muhammadiyah

Sinaga, Bethesda, Sri Lestari, Anita Camelia, Imelda G. Purba. 2013. Analisis Peningkatan Tekanan Darah Akibat Bising pada Operator di Pabrik Ammonia IB PT Pupuk Sriwidjaja Pelembang tahun 2013. Palembang : Universitas Sriwijaya

Soeripto. 2008. Higiene Industri. Jakarta : Balai Penerbit Fakultas Kedokteran Universitas Indonesia

Suma'mur. 2009. Higiene Perusahaan dan Keselamatan Kerja (HIPERKES). Jakarta : Sagung Seto.

Susanti, Ita. 2013. Pengaruh Pemakaian APD Ear Plug Terhadap Tekanan Darah Tenaga Kerja Terhadap Kebisingan Bagian Proses Tenun PT Iskandar Indah Printing Textile Surakarta. Artikel. Surakarta : Universitas Muhammadiyah

Tambunan, Sihar Tigor Benjamin. 2005. Kebisingan di Tempat Kerja (Occupational Noise). Yogyakarta : ANDI 